\title{
Mathematical model of the Late Pleistocene and Holocene transgressions of the Black Sea
}

\author{
N.V. Esin ${ }^{\text {a }}$ V. Yanko-Hombach ${ }^{\text {b,c, },}$, O.N. Kukleva ${ }^{a}$ \\ a Southern Branch of the P.P. Shirshov Institute of Oceanology, Oceanologiya, 353467 Gelendzhik-7, Krasnodar region, Russia \\ ${ }^{\mathrm{b}}$ Avalon Institute of Applied Science, 976 Elgin Ave, Winnipeg, MB R3E 1B4, Canada \\ ${ }^{\mathrm{C}}$ Scientific and Educational Center of Geoarchaeology, Marine and Environmental Geology, I. I. Mechnikov Odessa National University, Paleontological Museum, 2, \\ Dvorianskaia Str., Odessa 65082, Ukraine
}

\section{A R T I C L E I N F O}

\section{Article history:}

Available online 3 December 2009

\begin{abstract}
A B S T R A C T
Although the Late Pleistocene-Holocene fluctuations in the Black Sea have been studied over many years, no overall picture of this difficult natural phenomenon has as yet been developed and described. Moreover, in the literature, many researchers have provided mutually exclusive opinions about many of the processes occurring within this time interval.

The variation in conceptualizations about the filling of the Black Sea basin is explained by the following reasons. (1) Fluctuations of sea level in the basin were never properly studied as physical processes under conditions of increased freshwater runoff, change in Bosporus strait depth, increase in World Ocean level, etc. Therefore, some conclusions about sea-level changes were not verified by appropriate calculations and have not been physically substantiated. (2) The study of sea-level fluctuations are conducted according to modern sea depth markers and sediment age, but as the sediment was formed under varying depth conditions, and could have moved relative to modern markers by the agency of various geological processes, it is possible that that every core may give a different level curve. (3) Processes of sedimentation, erosion and redeposition of sediment occurring in the sea have been studied insufficiently. For this reason the same geological material has been interpreted differently by various researchers. Therefore, mathematical modeling of sea-level fluctuations based on various physical laws seems to be of great importance.

In this paper, the value and sign for the Black Sea freshwater balance during the Upper PleistoceneHolocene are discussed. The hypothesis suggests that during the specified period of time, the freshwater balance of the sea was always positive, the sea was filled with water up to the sill mark in the Bosporus strait, and a river flowed into the Sea of Marmara along the strait bottom. In the present paper, geologic evidence of the river flow in the strait during the glacial age and later is presented. Other points of view about the sea's freshwater balance change are considered.

A mathematical model of the Black Sea basin filling with freshwater in the Upper Pleistocene-Holocene is suggested. It considers that change in water volume inflowing to the Black Sea to be a result of ablation, neotectonic processes in the strait, bottom erosion, and sediment accumulation. Black Sea level change calculations have shown the following. As a result of repeated increases in river runoff during glacial melting, the level of the Black Sea started to rise from $-80 \mathrm{~m}$, probably to $-20 /-30 \mathrm{~m}$, making, in the process, numerous secondary fluctuations. The reason for this phenomenon was the circumstance that the water volume brought by the rivers could not flow to the Sea of Marmara through the narrow canyon of the Bosporus strait at the time. Therefore, water collected in the sea, raising its level. At approximately $12 \mathrm{ka}$ BP, the World Ocean level rose to the river surface and began to increase its depth. As a result of the increase in strait depth, the accumulated water in the Black Sea flowed out, thereby lowering its level to a mark close to the Ocean level. According to calculations, this occurred ca. $11 \mathrm{ka}$ BP. Thereafter, the Black Sea level rose together with the Ocean level. Water within the Sea of Marmara has flowed to the Black Sea since approximately $9 \mathrm{ka}$ BP in the form of a bottom counterflow. With a small time delay, theoretical change in the Black Sea level practically corresponds to data obtained from geological investigations.
\end{abstract}

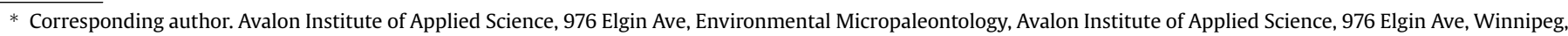
MB R3E 1B4, Canada. Tel.: +1 204 4894569; fax: +1 2044895782.
}

E-mail addresses: ovos_oos@mail.ru (N.V. Esin), valyan@avalon-institute.org (V. Yanko-Hombach), kuklev@ecologpro.ru (O.N. Kukleva). 
The theory offered here of fluctuations in Black Sea level is self-sufficient; it explains all processes from the melting of the glaciers, by physical laws and does not demand the application of any additional hypotheses. In the conclusion of this paper, the debatable questions about the Black Sea's possible lowering and the subsequent flooding of the basin are considered.

(C) 2009 Elsevier Ltd and INQUA. All rights reserved.

\section{Introduction}

Although the Holocene transgression of the Black Sea has been studied for many years, no overall picture of this difficult natural phenomenon has as yet been developed and described. Moreover, in the literature, many researchers have provided mutually exclusive opinions about many of the processes occurring during the Holocene. The Black Sea level curves and minimal level of the Postkarangatian regression introduced by different authors have proven to be incompatible.

The variation in conceptualizations about the filling of the Black Sea basin is explained, in our opinion, by the following reasons. (1) Transgression in the Black Sea basin has never been studied as a physical process under conditions of increased freshwater runoff, change in Bosporus strait depth, and increase in World Ocean level. Therefore, some conclusions about sea-level changes were not verified by appropriate calculations and have not been physically substantiated. (2) Transgression studies are conducted according to modern sea depth markers and sediment age, but as the sediment was formed under varying depth conditions, and could have moved relative to modern markers as a result of neotectonic movements, including different rates of uplift or submersion, every core probably gives a different level curve. (3) Processes of sedimentation, erosion, and redeposition of sediment occurring in the sea have been studied insufficiently. For this reason, the same geological material is interpreted differently by various researchers.

\section{Estimation of the value and sign of the Black Sea freshwater balance}

Value and sign of the Black Sea freshwater balance are the key parameters defining its change in level during the period when the World Ocean level was below the Black Sea level. If, in a glacial age, the freshwater balance was negative, the Black Sea would have exsiccated, its level would have dropped below that of the Bosporus strait, and the sea would have become a closed lake. If the balance was positive, sea level would have always been above the bed level of the strait, and excess freshwater would have flowed from the Black Sea into the Sea of Marmara. Some conclusions about the value and sign of the freshwater balance during a glacial age can be made from parameters of the present balance of the sea.

Parameters of the modern freshwater balance and its value, calculated by various authors, are presented in Table 1 (Joashvili, 2003). Averaged, the balance values are shown in the same table. The freshwater balance of the Black Sea ranges from +137 to $+300 \mathrm{~km}^{3} /$ year. Averaged by all authors, the parameters of freshwater balance are the following: river runoff, $+333 \mathrm{~km}^{3} /$ year; precipitation, $+214 \mathrm{~km}^{3} /$ year; evaporation, $-335 \mathrm{~km}^{3} /$ year. The averaged freshwater balance of the sea is $+212 \mathrm{~km}^{3} /$ year. In this balance, the river runoff is almost three times more than the difference between evaporation and precipitation.

There is a superabundance of freshwater in the Black Sea, as distinct from the Mediterranean. Its volume is slightly more than the Danube runoff. In a glacial age, the average annual air temperature of the region was $5-6 \%$ below that of the modern one. All the rivers flowed, which is known from overdeepened valleys, but parameters of the freshwater balance were less than modern values both because of climatic conditions and because the Black Sea's area at the time was less than the modern one.

On the basis of rather simple calculations, the hypothesis that during the glacial age the freshwater balance was positive, and excess water flowed through the Bosporus strait into the Sea of Marmara in the form of a river (Esin, 1987) was put forward. This hypothesis has allowed an explanation of some hydrological processes of the Pleistocene.

Kislov and Toropov (2005, 2006a,b) made a significant contribution to the solution of the problem of freshwater balance during the glacial age. Research conducted with the application of climatic models has shown that, in a glacial age, river runoff was $175.5 \mathrm{~km}^{3}$ / year, and evaporation and precipitation were $30-40 \%$ and $20-30 \%$ less than current values, respectively. This allows calculation of the freshwater balance of the Black Sea during the glacial age, when the level was at about $-100 \mathrm{~m}$, and the sea area was $24 \%$ less than the current one. For this purpose, in the averaged balance described above, values of evaporation and precipitation were first decreased by $24 \%$, and then by $40 \%$ and $30 \%$, respectively. The resulting values are: evaporation, $176 \mathrm{~km}^{3} /$ year; and precipitation, $98 \mathrm{~km}^{3} /$ year. Considering river runoff (176 km³ $/$ year in round figures), the freshwater balance was $+98 \mathrm{~km}^{3} /$ year. The balance was positive, considerable, and approximately equal to the total runoff of three rivers such as the Don.

It is necessary to note the following misunderstanding. In a number of works, Kislov and Toropov (2005, 2006a,b) assert, without corresponding calculations, that the Black Sea lowered to -150 to $-200 \mathrm{~m}$ during the glacial age. The theoretical research of Kislov and Toropov is considerable, and the authors accept their calculated parameters for freshwater balance. However, the negative value obtained for freshwater balance during the glacial age results from a debatable method, not from direct calculation (river runoff + precipitation - evaporation). In recent years, solid evidence has emerged indicating river flow in the Bosporus strait both in the glacial age and later.

Mudie et al. (2005), using 150 samples taken in the Black, Marmara, and Aegean Seas, noted desalinated conditions within these basins from 10.2 to $9.5 \mathrm{ka}$ BP. This indicates overflow of desalinated water from the Black Sea through the Sea of Marmara to the Aegean Sea with consequent desalination of the latter. According to Aksu et al. (2006), overflow of the Black Sea water began at $10 \mathrm{ka}$ BP.

Chepalyga (2005a,b, 2007) substantiates the existence of a river flowing through the Bosporus strait containing water with a low salt content during an earlier period. He has submitted data concerning the ancient delta of the river flowing from the Bosporus strait at 15-16 ka BP as well as sediment of $16 \mathrm{ka}$ age containing Caspian mollusc fauna.

Other geological research (Hiscott et al., 2002) confirms the existence of a river in the Bosporus strait flowing into the Sea of Marmara during the glacial age. The paleodelta of the river flowing from the Bosporus strait has been discovered in the Sea of Marmara. The river flowed during the glacial age (25.5-23.5 ka BP), and in the Holocene (10-9 ka BP).

Thus, there are data indicating desalinated water flowed from the Bosporus strait 9-10 ka, $16 \mathrm{ka}$, and 23-25 ka BP, i.e., both in the Holocene and in the glacial age. The same conclusion follows from the theoretical calculations discussed below. 
Table 1

Parameters of the modern freshwater balance and other characteristics of currents through the Bosporus strait (Joashvili, 2003).

\begin{tabular}{|c|c|c|c|c|c|c|c|c|c|c|}
\hline \multicolumn{11}{|c|}{ Water balance of the Black Sea according to different authors } \\
\hline \multirow[t]{2}{*}{ Author } & \multicolumn{5}{|c|}{ Water inflow ( $\mathrm{km}^{3} /$ year $)$} & \multicolumn{5}{|c|}{ Water discharge $\left(\mathrm{km}^{3} /\right.$ year $)$} \\
\hline & $\begin{array}{l}\text { River } \\
\text { runoff }\end{array}$ & $\begin{array}{l}\text { Atmospheric } \\
\text { precipitation }\end{array}$ & $\begin{array}{l}\text { Inflow from the } \\
\text { Azov Sea }\end{array}$ & $\begin{array}{l}\text { Inflow from the } \\
\text { Bosporus }\end{array}$ & Total & $\begin{array}{l}\text { Evapo- } \\
\text { ration }\end{array}$ & $\begin{array}{l}\text { Out-flow to the } \\
\text { Azov Sea }\end{array}$ & $\begin{array}{l}\text { Out-flow to the } \\
\text { Bosporus }\end{array}$ & Total & Balance \\
\hline $\begin{array}{l}\text { Shpindler and Vrangel } \\
\text { (1899) }\end{array}$ & 474 & 220 & & & 694 & 232 & & 416 & 648 & \\
\hline Merz (1928) & 328 & 231 & & 193 & 752 & 354 & & 398 & 752 & +205 \\
\hline Sverdrup et al. (1942) & 328 & 240 & & 192 & 760 & 363 & & 397 & 760 & +205 \\
\hline Zenkevitch (1947) & 320 & 145 & & 202 & 667 & 319 & & 348 & 667 & +146 \\
\hline $\begin{array}{l}\text { Rozhdestvensky } \\
\text { (1953) }\end{array}$ & 340 & 280 & & 195 & 815 & 240 & & 575 & 815 & +199 \\
\hline Leonov (1960) & 309 & 230 & 95 & 193 & 827 & 365 & 70 & 392 & 827 & +199 \\
\hline Bruevich (1960) & 350 & 225 & & 175 & 750 & 350 & & 400 & 750 & +225 \\
\hline Barenbeim (1960) & 340 & 120 & 59 & 193 & 712 & 280 & 34 & 398 & 712 & +205 \\
\hline Soliankin (1963) & 346 & 129 & 53 & 176 & 704 & 332 & 32 & 340 & 704 & +164 \\
\hline Ozturgut (1971) & 352 & 300 & & 249 & 901 & 353 & & 548 & 901 & +299 \\
\hline $\begin{array}{l}\text { Rozhdestvensky } \\
\text { (1971) }\end{array}$ & 294 & 254 & 38 & 229 & 815 & 301 & 29 & 485 & 815 & +256 \\
\hline Serpoianu (1985) & 336 & 120 & 53 & 123 & 632 & 340 & 32 & 260 & 632 & +137 \\
\hline Pora and Oros (1974) & 294 & 254 & 38 & 229 & 815 & 301 & 29 & 485 & 815 & +256 \\
\hline Fonselius (1974) & 320 & 230 & & 200 & 750 & 350 & & 400 & 750 & +200 \\
\hline Bondar (1986) & 364 & 119 & 50 & 203 & 736 & 332 & 31 & 371 & 734 & +168 \\
\hline Unluata et al. (1990) & 352 & 300 & & 312 & 964 & 353 & & 612 & 965 & +300 \\
\hline $\begin{array}{l}\text { Altman and Kumysh } \\
\text { (1986) }\end{array}$ & 338 & 238 & 50 & 176 & 802 & 396 & 33 & 371 & 800 & +195 \\
\hline Reshetnikov (1992) & 353 & 225 & 22 & & 600 & 370 & & 227 & 597 & \\
\hline Average & 338 & 214 & & & & 335 & & & & 210 \\
\hline
\end{tabular}

Sapropel formation in the Sea of Marmara shows that, during the glacial period, the river flowed through the Bosporus strait and transported water with a low salt content to the Sea of Marmara (Thunell et al.,1983, 1984; Hiscott et al., 2002). Forming a strong density gradient preventing vertical movements of sea water and oxygen transfer to the bottom layers is impossible without a considerable and constantly replenishing surface layer of water with a low salt content. In the homogeneous sea without a density gradient, water will be mixed to the bottom during the winter convection, since there are no forces preventing this process. The conclusion of Sperling et al. (2003) that sapropels could be formed in the Sea of Marmara without inflow of freshwater from the Black Sea requires modification, as it contradicts the physical logic of the formation of anoxic conditions. It is doubtful whether sapropel formation can be explained by the supply of a generous amount of organic matter to a sea with well mixed waters. Any estimation by geological methods of the brackish water volume entering the Marmara Sea from the Black Sea will always be understated, as long as only freshwater was evaporating from the surface. Only some of the water flowing through the strait took part in the formation of the brackish layer. Since the river runoff in the channel was small, it is difficult to reveal its existence.

\section{Mathematical model of the Black Sea filling with freshwater}

The equation describing change in the Black Sea level as a result of changes in freshwater balance in the general view is:

$S \frac{\mathrm{d} H}{\mathrm{~d} t}=W-Q$,

where $S=$ sea area, $H=$ sea-level height, $t=$ time, $W=$ freshwater balance, and $Q=$ volume of water flowing from the sea through the Bosporus strait.

In order to estimate $Q$, the solution for problems of viscous flow on a horizontal plane was used. The following ratio for water flow on a horizontal plane was obtained from simplified Navier-Stokes equations (Esin, 2007; Esin and Kukleva, 2007a,b):
$Q=\frac{g h^{3} l}{3 v} \sin \alpha$

where $g=$ gravitational acceleration, $h=$ depth of water flow, $l=$ flow width, $\nu=$ kinematic coefficient of viscosity, $\alpha=$ angle of slope of river surface to horizon plane. As $\alpha$ has an order $10^{-3}$, assume $\sin \alpha \approx \mathrm{d} h / \mathrm{d} x$.

In this case, water is flowing along the channel, the bottom of which is a plane leaning to the northern and southern sills composed of bedrock (Algan et al., 2001). In this form, equation (2) adequately describes the change in Don River depth depending on the value of liquid runoff and Azov Sea level (Esin and Zhiliajev, 1971). Adaptation of the model to real conditions has shown that the value of $\nu$ needs to be increased by an order because of turbulent flow in the river. The accepted value for the Don River is $\nu=3 \cdot 10^{-3} \mathrm{~m}^{2} / \mathrm{s}$.

Using the structure of equation (2), $Q$ is:

$Q=\frac{g h^{3} l}{3 v} \frac{H-h}{L}$

where $h=$ depth of the river at the strait end, and $L=$ the strait length. $H$ is measured from the river-bed level at the end of the strait (Fig. 1).

Taking into account the value of $Q$ the model of the Black Sea basin filling with freshwater is given by equation (3):

$S \frac{\mathrm{d} H}{\mathrm{~d} t}=W-\frac{g h^{3} l}{3 v L}(H-h)$.

The physical meaning of the process described by equation (3) is the same as filling a bucket: the more water that enters, the higher the water level in the bucket. In a steady state, the water level does not vary. Then, inflow is equal to out-flow throughout the section.

\section{Some laws pertaining to the Black Sea basin filling with river water}

According to the above conclusion about a positive freshwater balance in the Black Sea, it is presumed that the sea was an open 


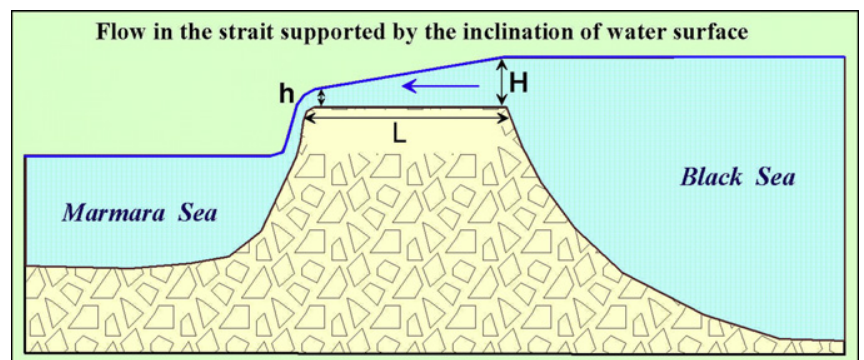

Flow in the strait provoked by the difference of sea levels

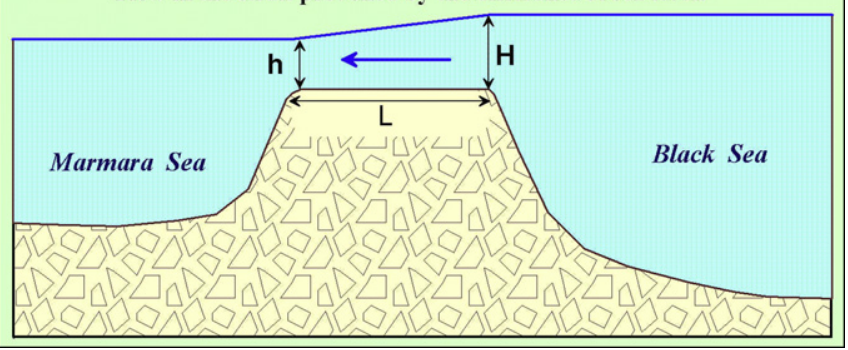

Fig. 1. Variations in hydrological conditions in the Bosporus strait given different positions of Marmara Sea level. a) The river flows in the strait. The Sea of Marmara has no influence on the flow velocity and water level in the river. b) Rising level of the Sea of Marmara increases the river depth and transforms it into the strait. Water discharge into the strait increases, and the level of the Black Sea decreases.

lake at the end of the glacial age, and its level was slightly above the Bosporus strait sill.

The solution of equation (3) reveals some laws of the Holocene transgression.

Consider the simplest case: the strait depth $(h)$ and freshwater balance $(W)$ do not change ( $h=$ const, $W=$ const), and at the initial time $H$ is set $(H=$ Ho when $t=0)$. In this case, the solution of equation (3) is given by:

$H=\frac{W v L}{g h^{3} l}+h+\left(H o-h-\frac{W v L}{g h^{3} l}\right) e^{-\frac{g h^{3} l}{v l S} t}$.

At $t \rightarrow \infty, H \rightarrow h+W \nu L / g h^{3} l$. Therefore, under steady-state conditions, sea level will be above the river surface at the strait output by a value of $W \nu L / g h^{3}$ l. At this level, river runoff will be equal to the value of the sea's freshwater balance. Its level will not change.

At present, the Black Sea level is stable. It is always higher than the Marmara Sea level by $0.3 \mathrm{~m}$, and it experiences seasonal fluctuations of several centimeters. This circumstance gives a possibility to estimate $v$ values for the present day situation, using the formula:

$H-h=\frac{W v L}{g h^{3} l}$,

where $H-\mathrm{h}=0.3 \mathrm{~m} ; \quad h=12 \mathrm{~m}, \quad l=1000 \mathrm{~m}, \quad L=30,000 \mathrm{~m}$, $W=412 \mathrm{~km}^{3} / \mathrm{yr}$ or $13,300 \mathrm{~m}^{3} / \mathrm{s}$. It is assumed that the bottom of the surface water flow in the Bosporus strait is an interface between surface flow and bottom counterflow. In the paper of Oguz et al. (1990), the profile of the interface for different values of water discharge in the upper flow is calculated. The average value of water discharge is close to the calculated one $\left(W=12,350 \mathrm{~m}^{3} / \mathrm{s}\right.$.). From the figures presented in this paper, it is seen that in the exit from the channel, the depth of this interface is about $10 \mathrm{~m}$. Having substituted in equation (3) values of the above-mentioned parameters, $v=7.5 \cdot 10^{-3} \mathrm{~m}^{2} / \mathrm{s}$. When comparing the suggested value of $v\left(3 \cdot 10^{-3} \mathrm{~m}^{2} / \mathrm{s}\right)$ and the one obtained from the solution of the inverse problem, we can conclude that they are close to each other. This is the validation of the model's representativeness.
The Late Pleistocene transgression was accompanied by climate warming. Judging from the changes in the World Ocean level, warming began at $21 \mathrm{ka} \mathrm{BP}$ and finished by $6 \mathrm{ka} \mathrm{BP(Rohde,} \mathrm{2007).} \mathrm{The}$ complete period of the cycle was 15,000 years. Ablation occurred in the following way. In the beginning, small volumes melted, and the process was intensified. As glacier volume decreased, melting diminished. Therefore, the volume of water inflowing to the Black Sea from glaciers can be approximated by the function:

$W=A\left(1-\cos \frac{2 \pi}{15,000} t\right)$

In this case, the solution to equation (3) will be:

$H=B \sin \left(\frac{2 \pi t}{1500}-\varphi\right)+C \mathrm{e}^{-a t}$,

where $B, \varphi, C, a=$ constant.

The solution (6) shows that rise of sea level $H$ is displaced in phase relative to $W$; when the freshwater balance of the sea started to decrease, the sea level kept rising for some time.

At a certain stage of the transgression, the ocean level rose to the level of the river surface in the strait, and from this moment onward, the strait began to be formed. Its depth increased, with the result that water flow from the Black Sea to the Sea of Marmara also increased. The position of the strait bottom changed at the same time due to tectonic movement, erosion, etc. The process by which the Black Sea basin filled with water is described by the equation:

$S \frac{\mathrm{d} H}{\mathrm{~d} t}=W-\frac{g l\left(h_{0}+m t\right)^{3}}{3 v L}\left[H-\left(h_{0}+m t\right)\right]+n S$,

where $m=$ rate of ocean-level increase, $n=$ rate of strait bottomlevel change as a result of erosion, accumulation, or tectonic movements, and $h_{0}=$ original strait depth. The solution of equation (7) shows that the sea-level oscillation dependence on freshwater balance and its fluctuations decreases with increasing strait depth (Fig. 2). With a strait depth of more than $10 \mathrm{~m}$, the level of the Black Sea is less than $1 \mathrm{~m}$ above the level of the Marmara Sea (it is currently $30 \mathrm{~cm}$ higher).

Numerous geological investigations (Balabanov, 2007) indicate that, along with global sea-level rise, secondary fluctuations with a periodicity of 600-700 years caused by ablation nonuniformity are observable. To consider this factor, we will add into equation (7) another term:

$k\left(1-\cos \frac{2 \pi}{700} t\right)$.

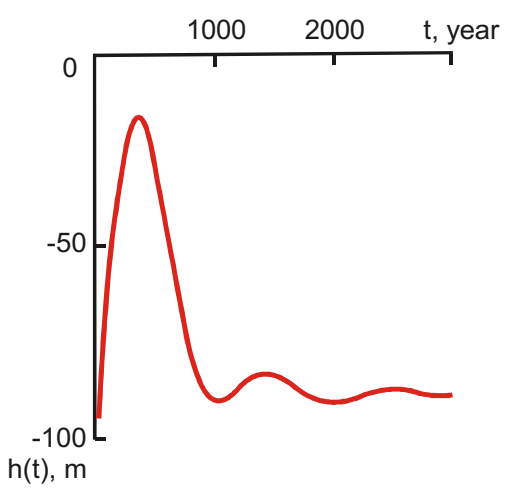

Fig. 2. Diagram demonstrating the decrease in amplitude of sea-level fluctuations under conditions of strait depth increase and the same fluctuations of the freshwater balance. 
The value of $k$, characterizing the maximum value of freshwater runoff fluctuations, is accepted as 10 times less than $A$. This model of the filling of the Black Sea basin is described as

$$
\begin{aligned}
S \frac{\mathrm{d} H}{\mathrm{~d} t}= & A\left(1-\cos \frac{2 \pi}{15,000} t\right)+0.1 A\left(1-\cos \frac{2 \pi}{700} t\right) \\
& -\frac{g l\left(h_{0}+m t\right)^{3}}{3 v L}\left[H-\left(h_{0}+m t\right)\right]+n S .
\end{aligned}
$$

In this form, the equation describing water balance in the Black Sea incorporates processes of level change that are subject to influences from both the World Ocean and uplift of the Bosporus strait sill.

\section{Reconstruction of paleoprocesses of the Upper Pleistocene-Holocene}

For reconstruction, ocean-level changes are considered to follow Rohde (2007). Judging from Fig. 3, warming began 21 ka BP, but in the beginning, glaciers melted very slowly. Then, the process accelerated, and by $7 \mathrm{ka} \mathrm{BP}$, the rate of World Ocean level rise slowed down again. Three segments within the ocean-level curve describe various rates of level rise. In the range from 21 to $15 \mathrm{ka} B P$, the average rate of ocean transgression was $3 \cdot 10^{-3} \mathrm{~m} / \mathrm{yr}$, in the range $15-7 \mathrm{ka} \mathrm{BP}, 13.3 \cdot 10^{-3} \mathrm{~m} / \mathrm{yr}$, and in the range from $7 \mathrm{ka} \mathrm{BP}$ to the present, $0.6 \cdot 10^{-3} \mathrm{~m} / \mathrm{yr}$.

The following initial conditions existed: the ocean level was at $-128 \mathrm{~m}$ at $21 \mathrm{ka}$ BP, the Black Sea level was at $-80 \mathrm{~m}$ (Kaplin and Selivanov, 1999; Yanko-Hombach, 2007; Yanko-Hombach et al., 2007a,b; Izmailov, 2008), and the strait sill was at $-73 \mathrm{~m}$.

The river flowing in the strait eroded the strait bottom at a rate of $2 \mathrm{~mm} / \mathrm{yr}$, and the bottom rose at a rate of $1 \mathrm{~mm} / \mathrm{yr}$ as a result of uplift of the crust. The rate of $1 \mathrm{~mm} / \mathrm{yr}$ was chosen because the calculated depth is close to the modern one.

Over the first 6000 years (from 21 to $15 \mathrm{ka}$ BP), ocean level rose by $3 \cdot 10^{-3} \mathrm{~m} / \mathrm{yr} \cdot 6 \cdot 10^{3}$ years $=18 \mathrm{~m}$, to $-110 \mathrm{~m}$. During this time, the strait bottom rose by $6 \mathrm{~m}$ and reached $-77 \mathrm{~m}$. The difference in elevation is $33 \mathrm{~m}$. Subsequently, the ocean level rose at a rate of $13.3 \mathrm{~mm} / \mathrm{yr}$, while the strait bottom rose by $1 \mathrm{~mm} / \mathrm{yr}$. Given this ratio, the ocean level would "catch up" with the strait bottom over $2.7 \mathrm{ka}$.

At that time, i.e., $12.3 \mathrm{ka}$ BP, the ocean level and the strait bottom were at $-74.3 \mathrm{~m}$. Increase in strait depth began when ocean level rose again, approximately $3 \mathrm{~m}$, occurring $12-11 \mathrm{ka}$ BP. At this

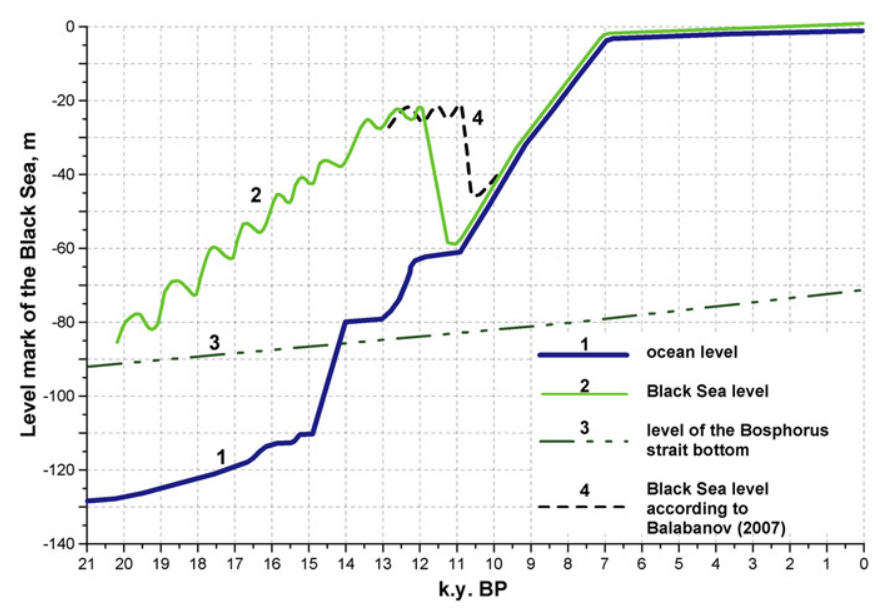

Fig. 3. Temporal fluctuations of the Global ocean level (Rohde, 2007), theoretical curve of Black Sea level fluctuations, curve of Black Sea level changes according to geological data (Balabanov, 2007), lifting of the northern sill in the Bosporus strait. moment, the strait bottom was at $-74 \mathrm{~m}$, and the ocean level was at $-71 \mathrm{~m}$. From here, the strait depth increased, and the Black Sea level went down, since conditions of water flow from the Black Sea to the Sea of Marmara improved. Regression of the sea level divides the Upper Pleistocene and Holocene at this time.

Over the next 500 years, until $10.5 \mathrm{ka}$ BP, the strait depth increased by $6.2 \mathrm{~m}$, reaching $9.2 \mathrm{~m}$. With this strait depth, ocean level was at $-64.3 \mathrm{~m}$, and the strait bottom was at $-73.5 \mathrm{~m}$. Flow rate in the strait decreased considerably, and silt accumulation on the strait bottom became possible. Considering that the rate of strait bottom rise was $3 \mathrm{~mm} / \mathrm{year}$, and the rate of increase in the strait depth was $13.3 \mathrm{~mm} / \mathrm{yr}$, the resulting rate of change was $10.3 \mathrm{~mm} / \mathrm{yr}$.

Formation of the bottom counterflow in the Marmara Sea, which led to the formation of near-bottom anoxic conditions and sapropel in the Black Sea, is the next significant stage of the Holocene transgression. According to Lane-Serff et al. (1997), the critical strait depth in which a counterflow can be formed is $11 \mathrm{~m}$. In this research, however, tangential stresses of upstream water in the Sea of Marmara forcing the upper layer of the bottom stream to flow back to the Sea of Marmara were not considered.

Interesting field data and theoretical calculations are presented in the paper of Oguz et al. (1990). This paper shows that when the volume of flowing water from the Black Sea becomes larger, from $4380 \mathrm{~m}^{3} / \mathrm{s}\left(138 \mathrm{~km}^{3} / \mathrm{a}\right)$ to $21,765 \mathrm{~m}^{3} / \mathrm{s}\left(686 \mathrm{~km}^{3} / \mathrm{a}\right)$, the interface between upper flow and counterflow above the sill drops $6 \mathrm{~m}$, and the depth of the counterflow decreases from 14 to $8 \mathrm{~m}$.

When water discharge through the strait was $10,500 \mathrm{~m}^{3} / \mathrm{s}$ $\left(330 \mathrm{~km}^{3} / \mathrm{yr}\right)$, a value close to that occurring after the ice melted, the depth of the counterflow above the sill would become $12 \mathrm{~m}$. If the Black Sea level dropped $12 \mathrm{~m}$, then the interface would abut against the sill, and counterflow would not be formed. In this case, the depth of the strait would be $24 \mathrm{~m}$. Such a conclusion can be made from a sufficiently reliable dynamic model. When the depth is $24 \mathrm{~m}$ or less, breaches into the Marmara Sea of limited volumes of water with salinity less than $38 \%$ are possible. Filling of the deep basin and formation of anoxic conditions on the bottom would be possible under the continuous current of salt water from the Marmara Sea. When such a current stops, the process of the Black Sea water desalination begins.

Taking a critical depth of $14 \mathrm{~m}$ as a basis, we can conclude that the Mediterranean water began to enter into the Black Sea by roughly $9.7 \mathrm{ka}$ BP. At first, water discharge within the bottom counterflow was small, but then it began to increase as a result of the influence of two factors: the strait depth's growth and a decrease in the freshwater balance of the Black Sea. However, since a theoretical curve of sea-level fluctuations is shifted in retrospect, the above-mentioned event took place several hundred years later. In this case, the most important fact is that it was a natural process depending on the depth of the strait and the difference between the water densities in the neighboring seas.

\section{Theoretical curve of the Black Sea level}

The basic stages of the Late Pleistocene-Holocene transgression of the sea follow upon the calculations proposed in the previous section. From the beginning of the transgression to $11 \mathrm{ka}$ BP, ocean level was below the level of the river in the Bosporus strait and did not affect the water level in the Black Sea. At this time, the strait bottom was rising at a rate of $1 \mathrm{~mm} / \mathrm{yr}$, i.e., in equation (2), $n=0$, $m=10^{-3} \mathrm{~m} / \mathrm{yr}$. In the range from 11 to $10.5 \mathrm{ka} \mathrm{BP}$, strait depth increased at a rate of $12.3 \mathrm{~mm} / \mathrm{yr}$, and as the rate of bottom elevation was $1 \mathrm{~m} / \mathrm{yr}$, and the rate of sea-level increase was $13.3 \mathrm{~mm} / \mathrm{yr}$, from equation (2) that $n=12.5 \mathrm{~mm} / \mathrm{yr}, \mathrm{m}=1 \mathrm{~mm} / \mathrm{yr}$. The rate of bottom uplift would be $3 \mathrm{~mm} / \mathrm{yr}$, and $n=12.5 \mathrm{~mm} / \mathrm{yr}$. 
In these calculations, it is assumed that the average width of the strait is equal to $600 \mathrm{~m}$, and length is $30 \mathrm{~km}$. The ablation period is 15,000 years, and the periodicity of secondary fluctuations in the freshwater balance is 700 years. Calculations were made separately for each of the periods, and final values for strait depth of the previous stage were accepted as initial values for the subsequent period. Segments of the sea-level curve resulting from these calculations were successively connected, and the resulting curve is presented in Fig. 3.

The resulting Black Sea level curve shows the following. In the range from 21 to $12 \mathrm{ka} \mathrm{BP}$, water level in the Black Sea rose and could have reached -20 to $-30 \mathrm{~m}$, which agrees with numerous geological (Balabanov, 2007) and micropaleontological data (Yanko-Hombach et al., 2007a,b).

Transgression was caused by repeated increases in the freshwater balance, which could have attained $40,000-50,000 \mathrm{~m}^{3} / \mathrm{s}$. All water flowing into the Black Sea could not have flowed through the strait, and thus it remained in the Black Sea, raising its level. During this period, sea level was unstable and reacted to changes in freshwater balance, even seasonal ones.

Regression during the 13-12 ka BP interval was caused by an increase in the depth of the Bosporus strait, with the result that water discharge through the river flowing within the strait increased. As a consequence, sea level declined over the next approximately 500 years, almost to the level of the World Ocean. At this time, the level within the Black Sea was not higher than $1 \mathrm{~m}$ above that of the ocean. Such a difference in sea levels enabled an overflowing of Black Sea freshwater balance into the neighboring sea. Further, the Black Sea level paralleled that of the World Ocean, staying several tens of centimeters above it. During the process of strait deepening, the difference in sea levels decreased. Now, the level of the Black Sea lies $30 \mathrm{~cm}$ above that of the Marmara Sea.

This model shows that the Upper Pleistocene to Holocene transgression had two maxima. The first one was caused by ablation, the second one by the increase in World Ocean level. Therefore, there were two transgressions in the Black Sea, Late Pleistocene and Holocene (Fedorov, 1978).

Calculation of Black Sea level change in the Holocene shows that the course of the World Ocean and that of the Black Sea was practically identical. This imposes considerable constraints on curves describing the process. Taking into account the abovementioned idea, secondary fluctuations with an amplitude up to $20 \mathrm{~m}$ would not be expected in the Holocene, as the strait was deep, and there could not be major fluctuation in the freshwater balance. Hence, a real transgression in the level was smoother and more uniform than was thought by previous researchers.

\section{Geological and other evidence supporting representativeness of mathematical model}

The most complete Holocene history of the Black Sea is presented in the paper by Balabanov (2007), where the analyzed results of tens, or maybe hundreds, of sites drilled on the Caucasian coast of the Black Sea, the Sea of Azov, in Crimea, and on the northwestern coast of Ukraine are summarized. Sites completely covered Holocene deposits, and in rare cases $60-70 \%$ of their thickness. This is the most representative unit of Holocene research on the Russian and Ukrainian coast of the Black Sea. Many dozens of papers have been written on the basis of its content.

The analysis of obtained material has shown that in the interval between 12.5 and $10.7 \mathrm{ka} \mathrm{BP}$, sea level rose at least three times up to $-20 /-24 \mathrm{~m}$. The most probable age of transgression peaks are 12.2, 11.6 , and $10.9 \mathrm{ka}$ BP. Intermediate peaks did not exceed several metres. In the beginning of the Holocene, between 10.7 and $9.9 \mathrm{ka}$ $\mathrm{BP}$, signs of a deep regression are recorded. Its traces were observed in the interval between $(10,530 \pm 190)$ and $(10,130 \pm 180) \mathrm{BP}$ at the different sections at depths from 40 to $-80 \mathrm{~m}$. Low depth is explained by tectonic submersion. On the basis of these descriptions, we drew a picture of changing sea level (Fig. 3).

Comparison of the theoretical curve and the one drawn on the basis of geological study has shown that the former describes change in the Black Sea level rather precisely but it is displaced in time by 1000 years, and secondary fluctuations are displaced in phase. All the other details are equivalent: transgression with secondary fluctuations, rapid regression (400-500 years), and ocean transgression, increase of channel depth, and breach of Marmara sea water in the near-bottom layer into the Black Sea. Thus, the modes describe all the main peculiarities of sea-level change between 13 and $8 \mathrm{ka}$ BP. It thus follows that the Black Sea desiccation was not possible because neighboring seas were connected to each other by a deep strait.

The material presented by Balabanov is confirmed by the results of investigations given in the paper of Murdmaa et al. (2003). Study of Core 521 sampled on the Black Sea shelf produced the same conclusions as described in Balabanov's paper.

Theoretical results concerning the Black Sea fluctuations are characterized by the following circumstances. At $20 \mathrm{ka} \mathrm{BP}$, a process of glacial melting and freshwater balance could have increased 10 times. The entering volume of water could not flow through a narrow canyon, which was the state of the Bosporus strait at that time. As a result, Black Sea level began to rise and reached $-20 \mathrm{~m}$. At this time, sea level reacted to all the fluctuations in freshwater balance, from seasonal to secular ones, i.e., as it rose, it underwent secondary fluctuations with different amplitudes and periods.

The second phase of the Holocene began when global ocean level reached the water level in the river, and the strait began to form. Strait depth began to increase rapidly and, over about 500 years, reached $12 \mathrm{~m}$. With this increase in depth, Black Sea water elevated by the strait flowed out to the Marmara Sea. This phenomenon is fixed as a regression of several tens of metres. It ended when the Black Sea level declined almost to that of the global ocean, being higher by not more than $1 \mathrm{~m}$.

The third stage of the Holocene was characterized by the Black Sea level almost completely repeating the fluctuations of the global ocean level, all the time being slightly higher. A near-bottom counterflow of Marmara Sea water took place in the deepened strait, and this conclusion agrees with the data of Hiscott et al. (2002). In this model, there is no place for the Black Sea to dry and for an overtopping of Marmara Sea water through the strait. It is very likely that such a natural process did not happen within the last $30 \mathrm{ka}$. A good coincidence of theoretical research and geological material testifies to the theory of a "deep" Bosporus strait (Major et al., 2002).

\section{Discussion of the possibility of the Black Sea drying in the Late Pleistocene-Holocene}

In previous sections, a succession of Black Sea level changes in the interval between 21 and $8 \mathrm{ka}$ BP was described on the basis of concept that the freshwater balance in the Black sea was always a positive one. But another point of view about the process of the Late Pleistocene-Holocene transgression is stated in the literature. According to it, the freshwater balance in the Black Sea in some periods became negative, and the sea drew down owing to evaporation. This point of view is presented in the papers of Ryan, and they are broadly discussed in connection with the hypothesis of the "biblical flood" in the Black Sea.

The hypothesis of Ryan et al. (1997) consists of the following. In the Holocene, climate in the Black Sea basin sharply changed, and the freshwater balance became negative. As long as levels of 
the Black and Marmara seas were lower than the Bosporus strait sill at that time, the Black Sea would have begun to dry, and its level would have declined from $-30 \mathrm{~m}$ to $-155 \mathrm{~m}$, i.e., about $125 \mathrm{~m}$. At around $8.4 \mathrm{ka}$ BP, the global ocean level rose above the depth of the sill within the strait. For a short period of time, the strait bottom was eroded to a considerable depth, and a vigorous flow of salt water from the Marmara Sea gushed into the Black Sea. Over the course of several years, this flow raised the Black Sea level to an initial mark of $-30 \mathrm{~m}$. The filling was on a biblical flood scale.

It is obvious that transformation of a sea possessing a large volume of surplus freshwater into a water body declining due to evaporation would be possible only under conditions of sharp climate change. But there are no data describing any considerable changes of climate. Moreover, palynological research tells us that the climate during the interval of 8.4-5.5 ka BP was damp (precipitation was $>600 \mathrm{~mm} / \mathrm{a}$ ) (Aksu et al., 1995; Mudie et al., 2005). At this time, continuous sea sedimentation took place at the depth of $69 \mathrm{~m}$. Hence, the sea could not be declining. Which transformations in the Black Sea freshwater balance need to happen for the initiation of drying? Considering calculations from the climate models of Kislov and Toropov (2006a,b), components of the freshwater balance in the Black Sea 8400 years ago were smaller than at present, yielding a freshwater balance value that was slightly smaller (or possibly larger). Assume that evaporation, river runoff, and precipitation were $20 \%$ smaller than today. The averaged freshwater balance is as follows: evaporation $-279 \mathrm{~km}^{3}$ / a or $-0.6 \mathrm{~m} / \mathrm{a}$, precipitation $+178 \mathrm{~km}^{3} / \mathrm{yr}$ or $+0.5 \mathrm{~m} / \mathrm{a}$, river runoff $+276 \mathrm{~km}^{3} / \mathrm{a}$ or $+0.6 \mathrm{~m} / \mathrm{a}$. Given these components, freshwater balance is $+0.5 \mathrm{~m} / \mathrm{a}$.

Evaporation of a $125 \mathrm{~m}$ water layer takes some time, which was very limited because, as late as $9 \mathrm{ka} \mathrm{BP}$, the sea was filled to the sill of the Bosporus strait, and a river ran within the strait. Let us assume that it took 300 years for sufficient evaporation to occur. Then, a mean rate of evaporation would be $0.42 \mathrm{~m} / \mathrm{yr}$. Hence, for the evaporation of $125 \mathrm{~m}$ of water over the course of 300 years, evaporation must have been $0.58+0.5+0.42=1.5 \mathrm{~m} / \mathrm{a}$, i.e., the evaporation rate must have increased 2.5 times. In this case, it would be twice as high as today. This context needs a serious explanation.

If one assumes that all rivers emptying into the Black Sea had dried up, then the value of freshwater balance would be $-0.1 \mathrm{~m} / \mathrm{a}$. In this case, it would take 1250 years for the sea to evaporate down to the level of $-155 \mathrm{~m}$. Thus, there are grounds for the following conclusion: evaporative draw down of the Black Sea could occur under certain conditions, but its historical occurrence in the Black Sea basin is impossible.

In order to validate Ryan's hypothesis about a disastrous and rapid filling of the Black Sea at $8.4 \mathrm{ka}$ BP, calculations have been made which simulate a flow of Marmara Sea water through the Bosporus strait and into the Black Sea bottom (Siddall et al., 2004). In the opinion of the author of these calculations, comparison of the obtained results with sea bottom relief shows that the Flood was indeed a real event. In the authors' opinion, such a comparison is ill-posed insofar as simultaneous equations and assumptions do not describe the process of moving heavy water into a sea containing lighter water. In fact, they describe a fluid flow on the land surface of the planet, where gravity force is smaller than on the Earth.

Equations elaborated upon in the calculation of channel flow were used to describe water flow. It is, in principle, inappropriate for the description of sea currents for the following reasons. Linear scales of bottom flow in Marmara Sea water are equal to kilometers and hundreds of kilometers along the horizontal plane and the first metres, or possibly the first tens of metres, in the vertical plane. It was considered that such a flow was one of viscous fluid within a boundary layer. To describe such a flow, one must base equations on a vertical coordinate axis, and terms must include derivatives of horizontal velocity on the vertical coordinate. Many addends with derivatives on the horizontal coordinate can be neglected, as they are several orders smaller that the derivatives on the vertical coordinate. In the above-mentioned equations, everything is done per contra: the vertical coordinate is generally absent, flow velocity is averaged in the vertical direction, and addends that describe friction between layers along the horizontal axes are retained. Such a set of equations describes a liquid flow in a horizontal plane that is considered a viscous fluid, and in a vertical one, as a frictionless liquid. Such a liquid cannot transmit motion or entrain upper layers of sea water, and that is what is really observed in the sea. Sea currents have no effect on it, respectively. Hence, it flows to the sea without influence, i.e., it flows as if along the land with zero shearing stress on its surface.

The process of heavy water flow within a less heavy one requires an insertion of terms which contain density differences between the heavy and less heavy waters. Also, the density of the heavier water must be changeable in time and in the vertical dimension. In the presented equation, there are no such multipliers. As well, the process of salt and freshwater intermixing is not taken into consideration. Under natural conditions, owing to this intermixing, water is washed out of the near-bottom flow, and the value of its discharge decreases downstream.

A conclusion can be drawn that, from all kinds of sea impact upon the near-bottom flow of heavy water, only one, namely the difference between water densities, is taken into account. This is done in a peculiar way: by the reducing the acceleration of gravity. Actually, in this paper, the flow of semi-perfect and semi-viscous liquid along the land surface of the planet, where gravity force is smaller than on the Earth, is considered. The Moon may be an example, where there is no water in the seas, and gravity is six times less than on the Earth.

As it is seen, the model does not describe any processes taking place in the sea, and therefore, it cannot be useful for an analysis of hydrological conditions during the Flood. In the considered case, the model describes only the process for which it has been elaborated. It describes water flow in a channel on land.

In Siddall's model, the process is considered from the moment when the depth of water flow in the channel became $10 \mathrm{~m}$. So, a subsequent assumption is taken from it: as soon as water in the Marmara Sea rose to the depth of sill in the channel, $10 \mathrm{~m}$ thick sedimentary layer was instantly eroded and the flood began. In reality the process proceeded differently. At first, a streamlet ran through the sill. Then, as the bottom erosion increased and the Marmara sea level rose, the depth of the streamlet became larger, and it turned into a river. The river width enlarged, and water discharge in it increased. Only some time later, the depth of the river reached $10 \mathrm{~m}$, and the Flood began. At this time, the following occurred in the Black Sea. At the initial stage of Marmara Sea water flowing into the Black Sea, its level continued to sink. Water salinity in it increased, both as a result of entering of the Marmara Sea water, and as a result of evaporation. At last, when the water discharge in the channel was $0.42 \mathrm{~m} / \mathrm{a}$ or $180 \mathrm{~km}^{3} / \mathrm{a}$ (as a guide), this process began the filling of the Black Sea basin. At first, water level rose slowly, then, as soon as the Marmara Sea level rose, water flow increased. Since the Marmara Sea level was rising with the rate of $13.3 \mathrm{~mm} / \mathrm{a}$, catastrophically rapid flooding of the Black Sea basin could be possible only in the final stage of the transgression. Nobody knows how much time it took for the flooding of the Black Sea basin. In Siddall's model, water discharge is considered to be constant. Factually, it was growing from zero constantly, until the beginning of level equalization with the neighboring sea. At the stage of leveling, water discharge in the channel decreased. Since the surface water layer had evaporated, the interface of heavy and 
light water rose. Finally, after the level equalization, the Black Sea turned into a homogenous one, without halocline and density gradient, which prevented the transportation of oxygen to the bottom layers.

After the climate returned to its initial state and replaced the negative sign of freshwater balance with a positive one, the process of freshening the upper water layer and formation of the halocline began. This process finally resulted in the appearance of anoxic conditions and hydrogen sulphide contamination.

Thus, after the level equalization of the Black and Mediterranean Seas, the process of sapropel formation on the bottom could not start after the re-establishment of normal Holocene climatic conditions, freshening of the upper water layer, and the consumption of oxygen in the layer of Mediterranean water.

To discuss the possibility of Black Sea desiccation, it would be very useful for the adherents of this hypothesis to calculate the time from the start of water runoff till the beginning of sapropel formation. It would also help to show in which time interval the climate of the Black Sea basin was arid, and why the value of evaporation increased in 2.5 times.

From the analysis of climatic and hydrological aspects of Ryan's hypothesis, no evidence of its reality was presented. However, there is evidence, including climate, showing that there was neither Black Sea drying nor water runoff through the Bosporus channel (Mudie et al., 2005).

Geological arguments in favor of Ryan's hypothesis are described in later papers. Geophysical and geological research on the shelf to the north of the Bosporus revealed two lithological unconformities and lithological features on the Black Sea bottom at a depth of $100 \mathrm{~m}$. They are interpreted as subaerial erosion features (Giosan et al., 2005; Mart et al., 2006). A layer lying under the low unconformity is considered as an eroded body. Its age is more than 40,000 years. Dislocated bedding that contains marine and freshwater shells covers it, and the age of this layer is 4400 years. In the hypothesis, the unconformities testify to the lowering of the Black Sea level as a result of its desiccation down a depth close to $-125 \mathrm{~m}$, a subsequent lake stage, then erosion of the paleoshelf by rivers, and after that, bottom erosion by the Marmara Sea flow, which resulted in flooding. As a result, catastrophic water flow partially destroyed the pre-existing river channels.

There are rather important discrepancies in the presented interpretation. First, if a catastrophic water stream runs down a steep slope composed of easily erodable sediments, then for several tens of years under low level erosion, it will wash the bottom down to the basement forming a deep canyon on the paleoshelf. However, according to the presented material, remains of river beds that have been formed not long before the flooding are in place on the bottom. This is evidence of the fact that the water stream running across the shelf did not have a large eroding force.

Second, if a catastrophic filling of the Black Sea basin had taken place (during several tens of years), a process of marine sedimentation started immediately afterwards. In this case, the age of the upper b stratification would not be 4400 years, but about 8000 years. A question emerges: why did no marine sediments accumulate during almost 4000 years?

The next interpretation of geological material does not have contradictions. At approximately $9 \mathrm{ka} \mathrm{BP}$, bottom counterflow formed in the channel. It began to wash out the bottom composed of erodable sediments. Today, according to calculations by Oguz et al. (1990), the velocity of the counterflow is from 1 to $1.5 \mathrm{~m} / \mathrm{s}$, the difference in water salinity, $20 \%(38 \%$ and $18 \%$ ), and the difference in density under a temperature of $15^{\circ}$ is $0.01615 \mathrm{~g} / \mathrm{cm}^{3}$. In the Early Holocene, Black Sea water salinity was 3\% (Mudie et al., 2005), and difference in salinity between the upper and lower flows was $35 \%$. The difference in density was $0.02825 \mathrm{~g} / \mathrm{cm}^{3}$. By the present day, the difference of density decreased 1.7 times. The solution of the sum in linear variation of near-bottom counterflow shows that current velocity is proportionate to the value of $\Delta \rho / \rho$, where $\Delta \rho$ is the difference of water densities and $\rho$ is the density of brackish water. Approximate estimation shows that if the salinity of the upper water layer today in the Black Sea is 3\% , then current velocity of the near-bottom counterflow will be from 1.7 to $2.5 \mathrm{~m} / \mathrm{s}$. But under such velocities, not only silt is washed out but condensed deposits, for example, clay (Esin et al., 1980). Hence, the velocity of the counterflow would be considerably greater than the modern one, and when the salinity of the upper layer of Black Sea water increases, the water density difference decreases and, consequently, the velocity of the bottom stream decreases, too. For this reason, the process of marine sedimentation started only at $4.4 \mathrm{ka}$ BP.

Note that underwater erosion by water or water flows with suspended sediments is observed everywhere in the Black Sea, and that erosion reaches considerable values (Esin et al., 1987). The probability of sea bottom erosion by suspension flow is given in the papers of Esin et al. (1991) and Esin (2003).

Interesting material about the sedimentation process in the Bosporus strait is presented in the papers of Algan et al. (2001) and Gökaşan et al. (2005). In the first paper, the sedimentary layer in the central part of the channel is described, and a profile of a basic channel bottom is presented. On the basis of obtained material, the authors conclude that Mediterranean Sea water entered the Black Sea at $5.3 \mathrm{ka}$ BP. But since a date of about $9 \mathrm{ka} \mathrm{BP}$ is indisputable, the authors assume that sedimentary layers formed in the interval between $9 \mathrm{ka}$ BP and $5.3 \mathrm{ka}$ BP were washed out due to erosion.

In the latter paper, analysis of the processes of channel bottom erosion is carried out and a conclusion made that water flow was directed from south to north, i.e., it may be either bottom counterflow or catastrophic surface water flow that provoked a quick flooding of the Black Sea. Algan et al. (2001) and Gökaşan et al. (2005) tend to the version of the "biblical flood," but in the present authors' opinion, their material suggests another hypothesis. Here, as was described above in the case of bottom erosion, after the "flood" ended at $8.4 \mathrm{ka}$ BP and until $5.3 \mathrm{ka}$ BP, there was no sedimentation on the channel's bottom. Any cogent explanation of this phenomenon is not given in the papers.

The bottom was eroded by near-bottom counterflow. It appeared about $9 \mathrm{ka}$ BP and increased as long as the depth of the channel became deeper. Heavier Mediterranean water was flowing along the bottom in the direction of its incline, irrespective of surface flow. It deepened the bottom but left recent easily-eroded sediment of the channel slopes (if a catastrophic surface flow of Mediterranean water ran along the channel, it would have washed out sediments of the slopes down to the bottom). As in process of bottom erosion described above, the velocity of the counterflow decreased as long as the upper layer salinity of the Black Sea water increased, and at about $5 \mathrm{ka} \mathrm{BP}$, sedimentation became possible. Thus, the proposed mechanism of Mediterranean water as a bottom counterflow explains both the mechanism of bottom erosion and the possibility of subsequent sedimentation.

The material given in the paper by Algan et al. (2001) does not demonstrate the separation of the Black and Marmara seas by the northern sill of the Bosporus strait, formation of lakes in the channel, and a Black Sea desiccation at 12-11 ka BP. A similar structure for the sedimentary cover would be the case if the river from the Black Sea ran along the channel. At 12-11 ka BP, the global ocean level was close to $-60 \mathrm{~m}$, and therefore the seas were connected by the strait. Since glaciers were melting during that period, and the Black Sea river runoff repeatedly increased, the Black Sea could not draw down. Thus, the scheme of the position of the Black Sea and ocean levels is contrary to real events: at 12-11 ka BP, the 
ocean level was close to $-60 \mathrm{~m}$, and it was higher than the northern sill; the Black Sea level was also a little higher than both the northern sill and the ocean level owing to a huge amount of freshwater entering the basin.

To sum up the discussion about the probability of a Black Sea desiccation, interpretation of lithodynamic processes in the channel and on the shelf serves as a basis for this hypothesis, and it is only indirect evidence of a sea-level lowering. As is shown in the present paper, interpretation of such processes can be more logical and without contradictions. There is no direct attestation of a Black Sea desiccation in the paper by Algan et al. (2001), but there are a number of papers based on data from drilling on the coast and in river valleys, which yield direct evidence that the Black Sea did not draw down since at least $12 \mathrm{ka}$ BP. This fact is confirmed by calculation. It would be useful for the promoters of the Black Sea draw down hypothesis to describe changes of sea level and all attendant processes with proper calculations and geological evidence. The main indicator of desiccation may be large fluctuations in evaporation, which were observed only in the Black Sea basin, but not in the Marmara and Caspian seas where the climate remained humid.

\section{Conclusions}

1. New geological research, results of calculations based on climatic models, and analysis of changes in modern freshwater balance under varying climatic conditions confirm the fact that the Black Sea freshwater balance was positive, and the sea was a flowing lake, during the glacial period, during the deglaciation period, and in Holocene. Excess water flowed out into the Marmara Sea as a river or a stream through the Bosporus strait.

Conditions for a Black Sea desiccation may appear when the region's climate becomes arid, evaporation increases 2-2.5 times compared with today, and the Danube River flows directly to the Marmara Sea.

2. The mathematical model presented above describes the process by which the Black Sea basin filled with freshwater. It takes into consideration the temporal changes of freshwater balance, rate of uplift of the strait's bottom, and geometry of the strait channel.

3. Calculation has shown the following:

During the interval from 20 to $12 \mathrm{ka} \mathrm{BP}$, the Black Sea level rose to $-20 \mathrm{~m}$, then it became unstable and underwent secondary oscillations with different amplitudes and periods. The rising sea level was caused by the fact that, during the melting of glaciers, river runoff was so great that all water did not manage to flow to the Marmara Sea through the long and narrow canyon, which the Bosporus was at the time. Water accumulated in the Black Sea and raised its level.

About 12 thousand years ago, the global ocean level "reached" the level of the river in the Bosporus strait and began to deepen it, transforming it into a strait. When the depth increased, conditions improved for water flow to the Marmara Sea. For this reason, water accumulated previously began flowing out of the Black Sea over a 500-600 year interval, and sea level declined from $-20 \mathrm{~m}$ down to $-60 \mathrm{~m}$. Such a regression separates the Late Pleistocene and Holocene.

After the regression, levels of the Black Sea and the World Ocean became almost equal. This happened when the strait depth was about $10 \mathrm{~m}$. With such a depth, or greater, the Black Sea level changed according to the fluctuations in freshwater balance with an amplitude not higher than $1 \mathrm{~m}$. As a whole, beginning from $11 \mathrm{ka}$ BP, the Black Sea level parallels the changes in Global Ocean level, always being higher by less than $1 \mathrm{~m}$. When the strait's depth became greater, the amplitude of these fluctuations diminished.
Therefore, fluctuations of the Black Sea level with an amplitude of $20 \mathrm{~m}$ as described in some papers, seem to be somewhat dubious.

According to calculations, roughly 9 thousand years ago, when the strait's depth exceeded $25 \mathrm{~m}$, larger quantities of heavier water from the Marmara Sea rushed into the Black Sea as a bottom counterflow. It took more time for the creation of anoxic conditions on the bottom, and for the beginning of sapropel formation.

4. The model excludes the possibility of surface water flow from the Marmara Sea through the strait, and any prospect of a catastrophic flood in the Black Sea.

5. The presented mathematical model is self-sufficient. It is based on the laws of hydromechanics, and it naturally explains all principal processes during the Late Pleistocene-Holocene, while necessitating no additional hypotheses to explain these phenomena. An important feature of this theory is that it describes the whole course of the post-glacial transgression, but not its particular stages. Here, parameters in effect at the end of one transgression stage are considered as initial conditions for the next stage. In the literature, initial conditions of a stage under consideration very often do not follow from the previous behavior of the transgression, but they are created artificially in compliance with the author's ideas. As an example, one could consider the position of the strait threshold and the levels of the Black Sea and World Ocean before the proposed catastrophic flood of 8400 years ago. For a serious discussion of a possibility of such a flood, it would be necessary to prove how such initial conditions might have come about.

\section{Acknowledgments}

The authors gratefully acknowledge the support and hospitality of the Romanian and Bulgarian organizers, the National Institute of Marine Geology and Geo-Ecology (GeoEcoMar), Bucharest, Romania, and the Department of Natural History of the Regional Historical Museum, Varna, Bulgaria for hosting the IGCP 521 Fourth Plenary Meeting and Field Trip. The first author expresses special gratitude to Mariana Filipova-Marinova and Tatiana Begun, whose efforts permitted him to participate in the Bulgarian part of the conference and to visit his colleagues in Varna. Prof. Allan Gilbert is especially thanked for editing the text and polishing the English. The authors express their thanks to the editor-in-chief, Prof. Norm Catto for the opportunity to revise the paper, and to all reviewers for their critical remarks, which allowed us to improve the substance of the article.

This study is a contribution to IGCP-521/INQUA 0501 and is financially supported by the Russian research grant RFFI-YUG No. 06-05-96687 and the joint Ukraine-Russia Research Project "Southern Black Sea region under Global Climate Change: Environment for the last $20 \mathrm{ka}$ and forecast for the 21 st century", Grant $\Phi 28.6 / 024$ (2009-2010).

\section{References}

Aksu, A.E., Hiscott, R.N., Mudie, P.J., Kaminski, M.A., Abrajano, T., Marrett, F. Yaşar, D., August 20-28, 2006. Pre-10 ka transgression of the SW Black Sea helves: seismic and core evidence. In: Yanko-Hombach, V., Buynevich, I., Chivas, A., Gilbert, A., Martin, R., Mudie, P. (Eds.), Extended Abstracts of the Second Plenary Meeting and Field Trip of IGCP-521 Project "Black Sea Mediterranean Corridor During the Last 30 ka: Sea Level Change and Human Adaptation". Odessa National University, Odessa, Ukraine, ISBN 966-318-554-6 pp. 4-5.

Aksu, A.E., Yaşar, D., Mudie, P.J., Gillespie, H., 1995. Late glacial-Holocene paleoclimatic and paleoceanographic evolution of the Aegean Sea: micropaleontological and stable isotopic evidence. Marine Micropaleontology 25, 1-28.

Algan, O., Cağatay, N., Chepalyga, A., Ongan, D., Eastoe, C., Gökașan, E., 2001. Stratigraphy of the sediment infill in Bosporus strait: water exchange between the Black and Mediterranean seas during the last glacial Holocene. Geo-Marine Letters 20, 209-218. 
Altman, E.N., Kumysh, N.I., 1986. Mnogoletniaia vnutrigodovaia izmentchivost balansa presnikh vod Chernogo moria. (Long-term within-year variability of freshwater balance of the Black Sea). Trudi GOIN 176, 3-18 (in Russian).

Balabanov, I.P., 2007. Holocene sea-level changes of the Black Sea. In: YankoHombach, V., Gilbert, A.S., Panin, N., Dolukhanov, P.M. (Eds.), The Black Sea Flood Question: Changes in Coastline, Climate and Human Settlement. Springer Dordrecht, The Netherlands, pp. 711-731.

Barenbeim, D.Ya, 1960. Kertchenskii proliv vo vremena Strabona v svete noveishikh dannikh ob izmenenii urovnia Chernogo moria. (Kerch strait in Strabon's time in the light of up-to-date information about Black Sea level change). Sovietskaia Arheologia 4, 42-52 (in Russian).

Bondar, C., 1986. Considerations on water balance of the Black Sea. Report on the chemistry of seawater. In: Proceedings of the XXXIII International Conference on Chemical and Physical Oceanography of the Black Sea, 2-4 June, Goteborg, Sweden.

Bruevich, S.V., 1960. O vodnom i solevom balance Chernogo moria. (About water and salt balance of the Black Sea). Trudi Instituta Oceanologii AN USSR 42 (in Russian).

Chepalyga, A.L., 2005a. Prototip Vsemirnogo Potopa? (Is it a prototype of the Deluge?) Znanie-Sila 12,1-5 (in Russian).

Chepalyga, A.L., October 8-15, 2005a. Influence of the late glacial Eurasian water flow (great flood) on the Black Sea - Mediterranean corridor (BSMC). In: YankoHombach, V., Buynevich, I., Chivas, A., Gilbert, A., Martin, R., Mudie, P. (Eds.) Extended Abstracts of the First Plenary Meeting and Field Trip of IGCP-521 Project "Black Sea - Mediterranean Corridor During the Last $30 \mathrm{ka}$ : Sea Level Change and Human Adaptation". Kadir Has University, Istanbul, Turkey, pp. 29-31.

Chepalyga, A.L., 2007. Late glacial great flood in the Ponto-Caspian basin. In: YankoHombach, V. Gilbert, A.S., Panin, N., Dolukhanov, P.M. (Eds.), The Black Se Flood Question: Changes in Coastline, Climate, and Human Settlement Springer, Dordrecht, pp. 119-148.

Esin, N.V., 1987. To a problem of the Black and Mediterranean seas levels correlation in Pleistocene. Vodnije Resursy 2, 72-76.

Esin, N.V., 2003. Suspension viscosity in gravitational sediment flow. Doklady Rossiskoi Akademii Nauk, Seria Geologiia 393 (1), 75-77.

Esin, N.V., September 8-17, 2007. Mathematical model for the filling of the Black Sea basin with water in the Holocene. In: Yanko-Hombach, V., Buynevich, I. Dolukhanov, P., Gilbert, A., Martin, R., McGann, M., Mudie, P. (Eds.), Extended Abstracts of the Joint Plenary Meeting and Field Trip of IGCP-521 "Black Sea Mediterranean Corridor During the Last $30 \mathrm{ka}$ : Sea Level Change and Human Adaptation", and IGCP 481 "Dating Caspian Sea Level Change". Southern Branch of the Institute of Oceanology, Russian Academy of Sciences and Demetra Beneficent Foundation, Gelendzhik (Russia)-Kerch (Ukraine), pp. 48-49. ISBN:978-5-85941-151-0.

Esin, N.V., Kukleva, O.N., 2007a. About some physical processes which took place in the Black Sea during Holocenic transgression. In: Zhindarev, L.A. (Ed.), Problems of Nearshore the Sea Coastal Zone Management and Sustainable Development. Materials of Conference. Krasnodar Publishing House, pp. 335-337.

Esin, N.V., Kukleva, O.N., September 8-17, 2007b. About the possible mechanism producing Black Sea level fluctuations during the Holocene In: YankoHombach, V., Buynevich, I., Dolukhanov, P., Gilbert, A., Martin, R., McGann, M. Mudie, P. (Eds.), Extended Abstracts of the Joint Plenary Meeting and Field Trip of IGCP-521 "Black Sea - Mediterranean corridor during the last $30 \mathrm{ka}$ : Sea Level Change and Human Adaptation", and IGCP 481 "Dating Caspian Sea Level Change". Southern Branch of the Institute of Oceanology, Russian Academy of Sciences and Demetra Beneficent Foundation, Gelendzhik (Russia)-Kerch (Ukraine), pp. 50-52. ISBN:978-5-85941-151-0.

Esin, N.V., Peshkov, V.M., Shlezinger, A.E., 1991. Erosion of sea bottom by sediments Geomorphology 2, 64-67.

Esin, N.V., Savin, M.T., Zhiliajev, A.P., 1980. Abrasion Process of the Sea Coast Hydrometeoizdat, Leninigrad, $200 \mathrm{pp}$.

Esin, N.V., Zakharov, V.E., Ismailov, D.F., Shlezinger, A.E., 1987. Plane underwate erosion of the Black Sea paleoslopes. Doklady Rossiskoi Akademii Nauk, Seria Geologiia 293 (6), 1445-1448.

Esin N.V., Zhiliajev A.P., 1971. About water surface profile calculation in estuary zone. In: Papers Presented at the Conference on the Questions of Kuban Region Geography, pp. 28-35.

Fedorov, P.V., 1978. Pleistotsen Ponto-Kaspiia. (The Pleistocene of the Ponto-Caspian). Nauka, Moscow (in Russian).

Fonselius, S., 1974. On the problem of the determination of the sedimentation in semiclosed sea areas. ICES Hydrographic Commission C 30, 6.

Giosan, L., Mart, Y., McHugh, C.M.G., Vachtman, D., Çağatay, M.N., Eris, K., Ryan, W.B.F., October 8-15, 2005. Lowstand Marmara and Black Sea shorelines. In: Yanko-Hombach, V., Buynevich, I., Chivas, A., Gilbert, A., Martin, R., Mudie, P. (Eds.), Extended Abstracts of the First Plenary Meeting and Field Trip of IGCP521 Project "Black Sea - Mediterranean Corridor During the Last $30 \mathrm{ka}$ : Sea Level Change and Human Adaptation". Kadir Has University, Istanbul, Turkey, pp. 55-57.

Gökaşan E., Algan O., Tur H., Görüm T., Ecevitoğlu B., Tok B., Birkan H., Türker A. October 8-15, 2005. High resolution bathymetric and seismic studies in the Strait of Istanbul (Bosporus): evidences of erosion along the strait, and a delta formation at the southern entrance. In: IGCP 521 "Black Sea - Mediterranean Corridor During the Last 30 ka: Sea Level Change and Human Adaptation". First Plenary Meeting, Istanbul, pp. 63-64.

Hiscott, R., Aksu, A., Yaşar, D., Kaminski, M., Mudie, P., Kostylev, V., MacDonald, J, Issler, F., Lord, A., 2002. Deltas south of the Bosporus strait record persistent Black Sea outflow to the Marmara Sea since $~ 10$ ka. Marine Geology 190, 95-118.
Izmailov, Ya.A., Octrober, 2008. The pre-Holocene deepening of river valleys in the Caucasian coastal area and estimation of the magnitude of the Antian Regression in the Black Sea. In: IGCP 521 - INQUA 0501 Fourth Plenary Meeting and Field Trip, Bucharest-Varna.

Joashvili, Sh., 2003. Rivers of the Black Sea. European Agency of the Environment Protection, Tbilisi, $186 \mathrm{pp}$

Kaplin, P.A., Selivanov, A.O., 1999. Izmenenia urovnia rossiskih morei I razvitie beregov. (Changes of Sea Level of Russian Seas and Coastal Evolution: Past, Present, Future). GEOK, Moscow (in Russian).

Kislov, A., Toropov, P., 8-15 October 2005. Black Sea and Caspian Sea level changes: links to the East European river runoff and global climate changes. In: YankoHombach, V., Buynevich, I., Chivas, A., Gilbert, A., Martin, R., Mudie, P. (Eds.), Extended Abstracts of the First Plenary Meeting and Field Trip of IGCP-521 Project "Black Sea - Mediterranean Corridor During the Last 30 ky: Sea Level Change and Human Adaptation". Kadir Has University, Istanbul, Turkey, pp. 84-86.

Kislov, A.V., Toropov, P.A., 2006a. Modelirovanie variatsii rechnogo stoka Vostochno-Evropeiskoi ravnini pri razlichnikh climaakh proshlogo. (Modeling of river runoff variations of East European plain at various climates of the past). Vodnije Resursi 33 (5), 515-526 (in Russian).

Kislov, A.V., Toropov, P.A., 2006b. Modelirovanie izmenenii urovnei Chernogo I Kaspiiskogo morei pri razlichnikh sostoianiakh klimatov proshlogo. (Modeling of the Black and Caspian Seas level changes at different climate conditions of the past). Vestnik Moskovskogo Universiteta, ser. 5. Geography 6, 9-13 (in Russian).

Lane-Serff, G.F., Rohling, E.J., Bryden, H.L., Chanrock, H., 1997. Postglacial connection of the Black Sea to the Mediterranean and its relation to the timing of sapropel formation. Paleoceanography 12 (2), 169-174.

Leonov, A., 1960. Regional'naia Oceanografiia. (Regional Oceanography). Part I. Gidrometeoizdat, Leningrad (in Russian).

Major, C., Ryan, W., Lericolais, G., Hajdas, I., 2002. Constraints on Black Sea outflow to the Sea of Marmara during the last glacial-interglacial transition. Marine Geology 190, 19-34

Mart, Y., Ryan, W., Çağatay, N., McHugh, C., Giosan, L., Vachtman, D., 2006. Evidence for intensive flow from the Bosporus northwards during the early Holocene. Geophysical Research Abstracts 8 Sref-ID: 1607-7962/gra/EGU06-A-02572.

Merz, A., 1928. Hydrographische Untersuchungen in Bosporus und Dardanellen. Neue Folge, A 18, 3-284. Bearbeitet von: L. moller, Veroff.Inst. Meereskunde Univ. Berlin.

Mudie, P.J., Marret, F., Aksu, A.E., Gillespie, H., 8-15 October 2005. Palynological evidence for climatic change, anthropogenic activity and outflow of Black Sea Water during the late Pleistocene and Holocene: centennial- to decadal-scale records from Black, Marmara and Aegean Sea cores. In: Yanko-Hombach, V., Buynevich, I., Chivas, A., Gilbert, A., Martin, R., Mudie, P. (Eds.), Extended Abstracts of the First Plenary Meeting and Field Trip of IGCP-521 Project "Black Sea - Mediterranean Corridor During the Last $30 \mathrm{ky}$ : Sea Level Change and Human Adaptation". Kadir Has University, Istanbul, Turkey, pp. 121-123.

Murdmaa, I.O., Ivanova, E.V., Levchenko, O.V., Merklin, L.R., Chepalyga, A.L., Lobkovskii, L.I., Artemieva, E.A., 2003. Poslelednikovie sobitia na severo-vostochnom shelfe Chernogo moria. (Postglacial events of the north-eastern shelf of the Black Sea). In: Laverov, N.P. (Ed.), Aktual'nie problemi oceanologii [Actual Problems in Oceanology]. Nauka, Moskva, pp. 298-317 (in Russian).

Oguz, T., Özsoy, E., Latif, M.A., Sur, H.I., Ünlüata, Ü, 1990. Modeling of Hydraulically Controlled exchange in the Bosporus strait. Physical Oceanography 20 (7), 945-965.

Ozturgut, E., 1971. Physical Oceanographic Study of the Bosphorus. University of Istanbul.

Pora, E.A., Oros, I., 1974. Limnologie si oceanologie (hidrobiologie). Ed. Did. şi Ped., Bucuresti.

Reshetnikov, V.I., 1992. Vodnii balans Chernogo moria i ego izmenenie pod vlianiem khoziastvennoi deiatel'nosti [Water balance of the Black Sea and its changes under anthropogenic activities]. Ph.D. thesis, Department of Geography, Moscow State University (in Russian).

Rohde, R.A., 2007. Image: Post-Glacial Sea Level. http://www.globalwarmingart. $\mathrm{com} /$.

Rozhdestvensky, A.V., 1953. Cherno morie i kraine brezhnite ezera. (The Black Sea and Coastal Lakes). Varna (in Bulgarian).

Rozhdestvensky, A.V., 1971. Postuplenie mramornomorskoi vodi v Cherno more i chernomorskii vodno-solevoi balans. (Inflow of the Sea of Marmara water into the Black Sea and the Black Sea water-salt balance). Izvestiia na Instituta po okeanografia i ribne stopanstvo 11, 5-32 (in Bulgarian).

Ryan, W.B.F., Pitman III, W.C., Major, C.O., Shimkus, K., Moskalenko, V., Jones, G.A., Dimitrov, P., Görür, N., Sakınç, M., Yüce, H., 1997. An abrupt drowning of the Black Sea shelf. Marine Geology 138, 119-126.

Serpoianu, G., 1985. Jes echanges d'ean par le Bosphore. Oceanologica acta 8 (4), 373378

Shpindler, I.B., Vrangel, F.F., 1899. Materiali po gidrologii Chernogo i Azovskogo morei, sobrannie v ekspeditsiakh 1890-1891 gg. [Materials on hydrology of the Black and Azov Seas collected in expeditions of 1890-1891]. Zap. po gidrografii. App. to v. 20. St. Petersburg (in Russian).

Siddall, M., Pratt, L.J., Helfrich, K.R., 2004. Testing the physical oceanographic implications of the suggested sudden Black Sea infill 8400 years ago. Paleoceanography $19,1-11$.

Soliankin, E.V., 1963. About water balance of the Black Sea. Oceanologia 6, 986-993.

Sverdrup, H.U., Johnson, M.W., Fleming, R.H., 1942. The Oceans: Their Physics, Chemistry, and General Biology. Prentice Hall Inc., New York.

Sperling, M., Schmiedl, G., Hemleben, C., Emeis, K.C., Erlenkeuser, H., Grootes, P.M., 2003. Black Sea impact on the formation of eastern Mediterranean sapropel S1? Evidence from the Marmara Sea. Palaeogeography, Palaeoclimatology, Paleoecology 190, 9-21. 
Thunell, R.C., Williams, D.F., Belyea, P.R., 1984. Anoxic events in the Mediterranean Sea in relation to the evolution of late Neogene climates. Marine Geology 59,105-134.

Thunell, R.C., Williams, D.F., Cita, M.B., 1983. Glacial anoxia in the eastern Mediterranean. Journal of Foraminiferal Research 13, 283-290.

Unluata, U., Oguz, T., Latif, M.A., Ozsoy, E., 1990. On the physical oceanography of the Turkish Straits. In: Pratt, J.L. (Ed.), Physical Oceanography of the Straits. NATO/ ASI Series. Kluwer Academic Publishers, Ibrtrecht, pp. 25-60.

Yanko-Hombach, V., 2007. Controversy over Noah's Flood in the Black Sea: geological and foraminiferal evidence from the shelf. In: Yanko-Hombach, V., Gilbert, A.S. Panin, N., Dolukhanov, P.M. (Eds.), The Black Sea Flood Question: Changes in Coastline, Climate and Human Settlement. Springer, Dordrecht, pp. 149-203.

Yanko-Hombach, V., Gilbert, A., Dolukhanov, P., 2007a. Critical overview of the Flood Hypotheses in the Black Sea in light of geological, paleontological, and archaeological evidence. Quaternary International 167-168, 91-113. IGCP 521 Black Sea - Mediterranean Corridor: Sea Level Change and Human Adaptation. Yanko-Hombach, V., Ignatov, E.I., Yanina, T.A., May 16-20, 2007b. Problemi ekologicheskoi bezopasnosti okruzhayuschei sredi Prichernomoria pozdnepleistotsenovimi-golotsenovimi kolebaniiami urovnia moria. (Problems of ecological safety of Prichernomorye region environment in connection with the Late Pleistocene - Holocene oscillations of sea level). In: Zhindarev, L.A. (Ed.) Materiali konferentsii "Problemi upravleniia i ustoichivogo razvitia pribrezhnoy zoni moria [Problems of Nearshore Coastal Zone Management and Sustainable Development]". Gelendzhik, pp. 306-310.

Zenkevitch, L.A., 1947. Fauna i biologicheskaia produktivnost' moria. (Fauna and Biological Productivity of the Sea), vol. 2. Sovetskaia Nauka, Moskva (in Russian). 